\title{
Learning to Critique and Adapt Science Curriculum Materials: Examining the Development of Preservice Elementary Teachers' Pedagogical Content Knowledge
}

\author{
CARRIE J. BEYER, ELIZABETH A. DAVIS \\ School of Education, University of Michigan, Ann Arbor, MI 48109-1259, USA
}

Received 24 January 2011; accepted 31 May 2011

DOI 10.1002/sce.20466

Published online 19 September 2011 in Wiley Online Library (wileyonlinelibrary.com).

\begin{abstract}
Teachers often engage in curricular planning by critiquing and adapting existing curriculum materials to contextualize lessons and compensate for their deficiencies. Designing instruction for students is shaped by teachers' ability to apply a variety of personal resources, including their pedagogical content knowledge (PCK). This study investigated a criterion-based approach to lesson plan analysis as one way to help preservice elementary teachers develop and use their PCK to plan instruction for students. Results show that the preservice teachers demonstrated a range of strengths and weaknesses in applying their knowledge of science assessment, science curriculum materials, and instructional strategies for teaching science. This range was influenced, in part, by the presence of alternative ideas about science teaching, the extent to which the original curriculum materials aligned with reform-based standards and practices, and the presence of prompts to use criteria in their analyses. Despite these factors, preservice teachers' PCK improved significantly over time when they had multiple opportunities to practice applying the same criterion in their analyses. Insights into science teacher knowledge and implications for science teacher education are discussed. $\quad$ (C) 2011 Wiley Periodicals, Inc. Sci Ed 96:130-157, 2012
\end{abstract}

Correspondence to: Carrie J. Beyer; e-mail: cjbeyer@umich.edu Accepted under the editorship of Gregory Kelly. 


\section{INTRODUCTION}

A growing body of research has investigated the ways in which teachers use curriculum materials to design and enact instruction (Bullough, 1992; Collopy, 2003, Drake \& Sherin, 2009; Enyedy \& Goldberg, 2004; Grossman \& Thompson, 2008; Pintó, 2004; Remillard, 1999; Squire, MaKinster, Barnett, Luehmann, \& Barab, 2003). This research has shown that effective teachers hold an analytical stance toward curriculum materials, critiquing and adapting them to achieve productive instructional ends. Critiquing materials here refers to evaluating a set of written materials by identifying its strengths and weaknesses and adapting materials refers to making changes to lesson plans to promote opportunities for student learning (Beyer \& Davis, 2009; Drake \& Sherin, 2009). We use the term "analysis" to refer simultaneously to both practices.

Teachers analyze curriculum materials for two primary reasons in the United States. First, school districts routinely adopt and mandate the use of published curricular programs (Ball \& Cohen, 1996; Ball \& Feiman-Nemser, 1988). These programs equip teachers with much needed resources but vary in quality. For example, many are inconsistent with reform-based standards and practices, failing to attend to alternative ideas, provide relevant representations and phenomena, and scaffold sense-making (Beyer, Delgado, Davis, \& Krajcik, 2009; Hubisz, 2003; Kesidou \& Roseman, 2002; Stern \& Roseman, 2004). Poor quality materials do not adequately support student learning and thus need to be adapted to overcome these limitations. Second, curriculum developers typically design curriculum materials for a wide audience and general context. Thus, teachers need to use curriculum materials in flexibly adaptive ways to meet the needs, interests, and experiences of their specific classroom (Barab \& Luehmann, 2003; Brown, 2009; Enyedy \& Goldberg, 2004; Pintó, 2004; Squire et al., 2003).

Even though critiquing and adapting curriculum materials are essential aspects of teaching practice, novice teachers encounter difficulties with these tasks (Davis, 2006; Grossman \& Thompson, 2008; Nicol \& Crespo, 2006; Schwarz et al., 2008). Teachers who do not know how to analyze curriculum materials in productive ways may fail to recognize the strengths and weaknesses in materials. In turn, they may make counterproductive changes or fail to make much needed modifications. Therefore, new teachers need support in learning how to critique and adapt curriculum materials. In this study, we examine how preservice elementary teachers engage in these authentic teaching tasks as they are supported in their science methods course.

\section{Theoretical Framework}

Teacher-Curriculum Materials Participatory Relationship. This study is grounded in the theoretical perspective that teachers and curriculum materials participate together in a collaborative relationship (Brown, 2009; Remillard, 2005). In contrast to other perspectives that view teachers as mere conduits for curriculum materials (e.g., Welch, 1979), this perspective views teachers as active agents who work together with curriculum materials to develop the planned curriculum and construct the enacted curriculum.

Curriculum materials play an active role in mediating this participatory relationship by enabling and constraining teachers' curricular decision making (Brown, 2009; Remillard, 2005). Shaped by historical, social, and cultural values, curriculum materials contain particular ideas that specify what science concepts are important to teach and what pedagogical methods are most effective. These material resources influence what teachers learn from curriculum materials and how they use them in practice (Cohen \& Ball, 1999). For example, curriculum materials describing innovative pedagogical approaches may promote changes 
in teachers' knowledge about how to teach the subject and ultimately result in changes in their practice.

Teachers also play an active role in the participatory relationship. As teachers read and interpret written materials, they draw upon their experiences, beliefs, knowledge, and instructional goals (Brown, 2009; Remillard, 2005). These personal resources help teachers bring meaning to the materials, influencing their pedagogical decisions in planning and teaching (Cohen \& Ball, 1999). For example, teachers may modify their materials to be responsive to their instructional goals and students' needs. Thus, not only do curriculum materials shape teachers' ideas and practices but teachers simultaneously shape curriculum materials as they use and adapt the materials in ways that address their own unique characteristics, needs, and goals.

Pedagogical Content Knowledge. Teachers' interactions with curriculum materials are mediated by their knowledge and beliefs about the subject matter, teaching, and learning (Brown, 2009; Collopy, 2003; Enyedy \& Goldberg, 2004; Pintó, 2004; Remillard, 1999; Squire et al., 2003). One personal resource of interest in this study is teacher's pedagogical content knowledge (PCK). PCK is the knowledge that teachers use to help their students develop a deep understanding of specific subject matter (Shulman, 1986). This subjectspecific knowledge results from an interaction among teachers' pedagogical knowledge, knowledge of context, and subject matter knowledge (Grossman, 1990).

PCK entails several knowledge components that work together to help teachers represent specific subject matter in ways that make it comprehensible to students. Magnusson, Krajcik, and Borko (1999) developed a model of PCK for science teaching that identified five components. This model has formed the theoretical basis for much research on science PCK (see Abell, 2007, for the use of the model in organizing research on science teacher knowledge). The five model components include (a) orientations toward science teaching, which entails an appreciation for the purposes for and general approaches to teaching science; (b) knowledge of students' understanding of science, which includes an awareness of the prerequisite knowledge that students need and the difficulties they typically face when learning scientific subject matter; (c) knowledge of science curricula, which includes familiarity with science learning goals and curricular programs; (d) knowledge of science instructional strategies, which entails insight into strategies for teaching science, in general, and for teaching science topics, specifically; and (e) knowledge of science assessment, which includes knowing what outcomes to assess and how to assess these outcomes. Within each of these dimensions, teachers need to develop PCK not only for science topics but also for scientific inquiry practices (Davis \& Krajcik, 2005; Zembal-Saul \& Dana, 2000). This entails learning how to engage students in asking and answering scientific questions, exploring phenomena, making predictions about the outcome of investigations, collecting and analyzing data, and developing explanations based on evidence (National Research Council [NRC], 1996).

Like other researchers (Ball \& Bass, 2000; Hill \& Ball, 2008), our view of PCK entails examining not simply what teachers know but rather how they are able to use what they know in practice. "Knowing" something might reflect a static view of PCK-an expression of teachers' ideas devoid of a particular context or situation. For example, teachers may have ideas about the typical difficulties students face with a particular topic or useful strategies or representations for teaching particular areas. However, "using" knowledge entails a more dynamic view of PCK, where teachers flexibly apply their knowledge to a particular task. From this perspective, teachers engage in complex reasoning processes. These may include selectively retrieving knowledge they think is most relevant and using 
that knowledge in flexible ways to address a particular situation. When using their PCK in practice, teachers may also think about and combine their knowledge in new ways, resulting in the development of new knowledge. PCK needs to be responsive to a range of pedagogical activities in both teaching and planning (Ball \& Bass, 2000) - the latter being the focus of this study. In using their knowledge of students, pedagogy, and content to plan, teachers read and interpret curriculum materials in selective ways, reason about their strengths and weaknesses, and in turn, use their appraisals to make decisions about how to use and adapt the materials for instruction with students.

\section{Purpose of the Study and Research Questions}

Even though PCK plays an important role in shaping how teachers critique and adapt curriculum materials (Brown, 2009; Remillard, 2005), many novice teachers are just beginning to develop this knowledge base (Abell \& Roth, 1992; van Driel, Verloop, \& de Vos, 1998; Zembal-Saul, Blumenfeld, \& Krajcik, 2002) and thus encounter challenges in learning to plan lessons. For example, some preservice and beginning teachers follow their curriculum materials as written because they do not feel comfortable making changes to them (Ball \& Feiman-Nemser, 1988; Grossman \& Thompson, 2008). Other new teachers change their materials, but their adaptations are often limited to the practical and affective aspects of teaching (Lloyd \& Behm, 2005; Nicol \& Crespo, 2006; Schwarz et al., 2008). Still others struggle with addressing weaknesses, making superficial changes that do not address the weaknesses or unproductive changes that distort the point of the materials (Ball \& Feiman-Nemser, 1988; Grossman \& Thompson, 2008; Nicol \& Crespo, 2006). These challenges highlight the need to support novice teachers in developing and applying their PCK as they engage in curricular planning. Unfortunately, few studies have examined this topic, particularly how preservice elementary teachers' apply their knowledge in the adaptation of science curriculum materials (Beyer \& Davis, 2009; Davis, 2006; Forbes \& Davis, 2010; Schwarz et al., 2008). This study addresses these gaps by investigating how 24 preservice elementary teachers in a science methods course develop and use their PCK to identify strengths and weaknesses in science curriculum materials and make productive adaptations in planning for instruction.

To support the preservice teachers in these analysis tasks, we provided the preservice teachers with two types of scaffolds. We define scaffolds as temporary supports that enable learners to engage in complex tasks that they would, otherwise, be unable to do on their own (Wood, Bruner, \& Ross, 1976; see also Hogan \& Pressley, 1997; Stone, 1993; Tabak, 2004). Researchers have argued that scaffolds need to be gradually faded as individuals are able to complete increasingly more complex aspects of the task on their own (Collins, Brown, \& Newman, 1989; Pea, 2004). In this study, we provided the preservice teachers with prompts to use a criterion-based approach to analysis and a set of reform-based criteria representing key ideas about effective science teaching. Preservice teachers used these scaffolds to analyze three lesson plans provided by their course instructor. In general, the preservice teachers practiced applying each criterion once across these lesson plans. Wood and colleagues (1976) argued that the repetition of scaffolds may help learners apply what they have learned in one task to a later activity. Therefore, preservice teachers also applied one criterion across all three lesson plans. In addition, the preservice teachers analyzed two lesson plans from their field placements. Like the other analyses, we provided the preservice teachers with prompts to use a criterion-based approach to analysis but allowed them to choose the criteria for their analysis. Finally, preservice teachers completed a preand posttest that asked preservice teachers to critique and adapt a lesson without the use 
of any of the scaffolds. Given this set of assignments, we asked the following research questions:

1. What are strengths and limitations in preservice elementary teachers' PCK when using reform-based criteria to analyze science curriculum materials?

2. How does preservice elementary teachers' PCK change over time after applying criteria in the analysis of science curriculum materials?

This study informs the field of science teacher education by providing important insights into science teacher knowledge. It also has important implications for teacher educators preparing novice teachers to use science curriculum materials to plan and teach lessons.

\section{METHODS}

\section{Research Context and Participants}

This research study focused on one elementary science methods course at a large midwestern university in the United States. This course took place during the third semester of an undergraduate teacher education program. The program included three semesters of university coursework and field observation in elementary schools and one semester of full-time student teaching. Preservice teachers typically entered the program during their third year of college. The elementary science methods course met for 3 hours each week during the Fall semester of their final year of college.

The first author was, at the time of the study, a graduate student teaching the science methods course for the first time, after having apprenticed in the class twice. The second author served as the lead faculty member for the course. The course was organized around three overarching goals (Davis \& Smithey, 2009). The course aimed to help preservice teachers engage in inquiry-oriented science teaching, attend to students' ideas about science, and critique and adapt curriculum materials. All three course goals played an important role in this research study, with the third goal serving as the main focus.

Twenty-four (of 28) preservice elementary teachers consented to participate in the study. We informed them that they could withdraw at any time, and we would use pseudonyms to maintain confidentiality. Participants were similar to the population of elementary teachers in the United States (National Center for Education Statistics, 2007)_primarily White (21/24) and female (24/24). Most were also traditional fourth-year college students (21 or 22 years of age) in their final year of study.

Regarding their college academic preparation, participants completed both general studies courses distributed over five subject matter areas (language arts, natural science, social science, mathematics, and fine arts) and a teaching major in one of these areas. The participants in this study majored in language arts $(12 / 24)$, mathematics $(5 / 24)$, social studies $(6 / 24)$, or science (1/24). The participants also engaged in professional coursework. Prior to the science methods course, preservice teachers completed courses in foundations of education, educational psychology, multicultural education, and teaching methods in literacy and social studies. Regarding their science academic preparation, three fourths of the class reported taking only primary science courses - biology, chemistry, and physics—and taking two or fewer of these courses at the college level.

\section{Instructional Context: Learning About Reform-Based Criteria}

Like others (Schwarz et al., 2008), we developed a set of reform-based criteria based on the American Association for the Advancement of Science Project 2061 Instructional

Science Education, Vol. 96, No. 1, pp. 130-157 (2012) 
Analysis Criteria (Kesidou \& Roseman, 2002; Stern \& Roseman, 2004). (The Project 2061 criteria are based on existing research about student learning and used at the national level to analyze science curriculum materials.) By providing the preservice teachers with criteria, we aimed to develop their capacity to use their PCK in planning curriculum-based lessons.

As written, the Project 2061 framework includes several criteria organized into seven categories representing key aspects of teaching practice, and each criterion includes indicators and a scoring rubric for judging how well the curriculum materials meet each criteria. In the science methods course, we focused on six of these categories and added one category. We also modified the framework to focus the analyses at a larger grain size. Specifically, what Project 2061 called "categories," we described as "criteria," and what Project 2061 called "criteria," we described as "indicators" for meeting each criterion. We did not include any scoring rubrics.

We based the above modifications on several factors. First, the Project 2061 criteria are intended for use in analyzing textbooks, not individual lesson plans. Second, extensive training is required before one can use the analysis framework - an opportunity not afforded by the time constraints of a one-semester course. Third, preservice teachers were not likely to view curricular analysis as an authentic task if asked to use the Project 2061 criteria aswritten since classroom teachers do not use scoring rubrics for lessons in their daily work (Schwarz et al., 2008). Finally, we hypothesized that focusing at a larger grain size would provide a more accessible entry point for learning about curricular analysis, especially for novices learning about it for the first time.

The reform-based criteria used in this study included (1) attending to learning goals, (2) establishing a purpose, (3) eliciting students' prior knowledge and predictions, (4) providing experiences with phenomena, (5) promoting students' sense-making, (6) assessing student learning, and (7) making science accessible for all students. These criteria focus on ideas and strategies specific to the discipline of science but not necessarily to a specific domain (e.g., chemistry, biology), topic (e.g., solubility, oxidation), or practice (e.g., modeling, predictions). Thus, these criteria and their respective indicators aimed to develop preservice teachers' PCK for teaching science in general, or what Veal and MaKinster (1999) term "general PCK," though this PCK would, in turn, later be developed in domain-, topic-, and practice-specific ways.

\section{Data Sources}

Pre/Posttests. The preservice teachers completed a pretest and posttest at the beginning and end of the course, respectively. In each, they analyzed the same lesson plan, which focused on helping fourth and fifth graders learn about the process of melting by having them design a container that would keep an ice cube frozen for as long as possible. The pre/posttests asked the preservice teachers to describe the strengths and weaknesses of the lesson plan and modify it to address its weaknesses. We used this data source to describe how preservice teachers critiqued and adapted science lessons within an open-ended task, shedding light on their PCK and on any changes in their ideas and abilities after experiencing the science methods course.

Lesson Plan Analysis Assignments. One 3-hour class session was devoted to learning about each criterion. The preservice teachers participated in activities and discussions about readings to develop their ideas about the criteria. They then practiced applying the criteria in three lesson plan analysis assignments. These tasks aimed to develop preservice teachers' capacity to apply their PCK in analyzing lesson plans. They analyzed an inquiry-oriented 
science lesson plan for each assignment. In the first assignment, the lesson plan had first and second graders identify waterproofing as one property of materials by testing the ability of different materials to keep a cotton ball dry. The lesson plan for the second assignment engaged second and third graders in investigating the seed dispersal methods of different types of seeds. In the third assignment, the lesson plan had fifth graders learn about friction by testing how far a toy car travels on different surfaces.

These assignments prompted preservice teachers to use three specific criteria in each analysis. For each criterion, the preservice teachers identified aspects of the lesson plan that met or did not meet each indicator, provided examples from the materials to justify their ideas, and described adaptations to improve the lesson. Preservice teachers applied Criteria 1 and 2 in the first assignment, Criteria 4 and 5 in the second assignment, Criteria 6 and 7 in the third assignment, and - to see whether additional practice would support the development of PCK-Criterion 3 in all three assignments. Criterion 3 focused on strategies for eliciting both students' prior knowledge about the new content and predictions about the phenomena. The preservice teachers considered both types of ideas together in the same criterion for two reasons. First, both are examples of the types of initial ideas that teachers elicit at the beginning of the lesson. Therefore, having the preservice teachers consider both types of ideas together in their analysis enabled them to recognize that they needed to elicit both in the introduction of the lesson before engaging students in the investigation or experiment. Second, we hypothesized that the preservice teachers might struggle with differentiating between the two types of ideas. Therefore, having the preservice teachers consider strategies for eliciting students' prior knowledge and predictions within the same criterion might help them recognize and resolve any confusion they might between the two, and in turn, develop a more robust understanding of each.

After each analysis, the instructor provided written feedback on assignments, noting the accuracy and usefulness of their claims and adaptations and providing detailed explanations clarifying how particular ideas were inaccurate or incomplete and how they could be improved. In the class session following the assignment, the instructor summarized the main strengths and weaknesses in the application of preservice teachers' PCK, giving examples to illustrate both accurate and inaccurate ideas and discussing any questions raised by the class.

We used this data source to describe how well preservice teachers applied reformbased criteria in their analysis of inquiry-oriented science lesson plans. These assignments shed light on preservice teachers' ability to apply their PCK in curricular analysis, when provided with prompts to use a criterion-based approach to analysis and reform-based criteria as scaffolds.

Reflective Teaching Assignments. Unlike other studies that have only investigated preservice teachers' analysis of instructor-provided curriculum materials (Beyer \& Davis, 2009; Davis, 2006; Lloyd \& Behm, 2005; Nicol \& Crespo, 2006; Schwarz et al., 2008), this study also enabled preservice teachers to analyze lessons in two authentic analysis experiences. The preservice teachers completed two reflective teaching assignments at the middle and end of the course. For these assignments, the preservice teachers obtained lesson plans from their mentor teacher; these lesson plans were not typically very inquiry oriented (Forbes \& Davis, 2010). The preservice teachers then analyzed each lesson using criteria, developed a revised lesson plan, and enacted the lesson in their field placement. (We collected only the written lesson analyses and revised lesson plans, not records of the lesson enactments, since this study focused exclusively on describing preservice teachers' PCK in planning science lessons.) Like the lesson plan analysis assignments, the preservice 
teachers applied three criteria by identifying aspects of the lesson plan that met or did not meet each indicator, justifying their ideas, and suggesting adaptations. The preservice teachers chose the criteria for their analysis.

These tasks aimed to further develop the preservice teachers' PCK in the following ways: Engaging in authentic analysis experiences provided the preservice teachers with the opportunity to see the criteria from the lesson plan analysis assignments as relevant, motivating their use of the criteria in their future teaching practice. These experiences also provided the preservice teachers with additional practice in identifying the strengths and weaknesses of curriculum materials and making productive adaptations using some of the reform-based criteria. In addition, providing the preservice teachers with the freedom to choose the criteria enabled them to decide which criteria were most relevant for their analysis and empower them as autonomous curriculum decision makers.

We used this data source to describe how well the preservice teachers attended to features of reform-based science teaching in their lesson plans that they were responsible for teaching in their placements. These assignments shed light on preservice teachers' capacity to apply PCK in planning their own science lesson plans, when prompted to use criteria in these planning tasks.

Limitations in Data Sets. This set of assignments offers many opportunities to describe PCK within preservice teachers' curricular planning practices, as described above, but it also has some limitations. This data set sheds light on some aspects of preservice teachers' PCK but not all-specifically, this data set does not illuminate much about preservice teachers' orientations toward science teaching or knowledge of students' understanding of science. In addition, the assignments provided the preservice teachers with some degree of support. For example, the lesson plan analysis assignments and reflective teaching assignments prompted the preservice teachers to use criteria in their planning, and the pre/posttests, in addition to these two assignments, asked the preservice teachers to articulate, in writing, the strengths and weaknesses of lessons, adaptations they would make, and the rationales underlying their pedagogical decisions. These design features are not authentic to teaching practice; therefore, these assignments provide only approximations of practice for studying preservice teachers' PCK (Grossman et al., 2009). Finally, these data sets do not provide insight into the application of PCK in the rigors of day-to-day classroom planning and instruction.

\section{Data Coding and Analysis}

We coded all of the data for how well the data addressed the indicators of each reformbased criterion. We created a list of codes based on the reform-based criteria and subcodes based on the indicators. The preservice teachers received the criteria and indicators as part of the lesson plan analysis assignments. Table 1 includes the codes and subcodes used in the analysis.

For each indicator, we analyzed the preservice teachers' response to determine whether they understood the intent of the indicator, defined as giving an accurate claim about whether the lesson plan met the indicator or not and the presence of correct examples to support their claim (for a similar approach, see Schwarz et al., 2008). Responses demonstrating understanding of the indicator received one point and responses demonstrating no understanding received zero points. For each preservice teacher, we then added up points based on how many indicators were accurately addressed. Since each criterion had three indicators, the maximum score for a given criterion was three. 
TABLE 1

Coding Scheme for the Application of the Reform-Based Criteria

\begin{tabular}{|c|c|c|}
\hline Code & Subcode & Example \\
\hline \multirow[t]{3}{*}{$\begin{array}{l}\text { Attending to } \\
\text { learning goals }\end{array}$} & $\begin{array}{l}\text { Address content and } \\
\text { inquiry }\end{array}$ & $\begin{array}{l}\text { Learning goals address both science } \\
\text { content and inquiry }\end{array}$ \\
\hline & Connection to standards & $\begin{array}{l}\text { Learning goals are grade-appropriate } \\
\text { and aligned with standards } \\
\text { documents }\end{array}$ \\
\hline & Alignment with lesson & $\begin{array}{l}\text { Learning goals are aligned with } \\
\text { activities and assessments }\end{array}$ \\
\hline \multirow[t]{3}{*}{$\begin{array}{l}\text { Establishing a } \\
\text { purpose }\end{array}$} & Explicit purpose & $\begin{array}{l}\text { Lesson prompts teacher to make } \\
\text { lesson purpose explicit to students }\end{array}$ \\
\hline & Meaningful purpose & $\begin{array}{l}\text { Purpose is likely to be meaningful to } \\
\text { students and anchored in the lives } \\
\text { of learners }\end{array}$ \\
\hline & Connected purpose & $\begin{array}{l}\text { Lesson helps teacher connect the } \\
\text { purpose to what students have been } \\
\text { learning about thus far in class }\end{array}$ \\
\hline \multirow[t]{3}{*}{$\begin{array}{l}\text { Eliciting students' } \\
\text { prior knowledge } \\
\text { and predictions }\end{array}$} & $\begin{array}{l}\text { Elicit ideas and } \\
\text { predictions }\end{array}$ & $\begin{array}{l}\text { Lesson enables teacher to elicit } \\
\text { students' ideas about the new } \\
\text { content and predictions about } \\
\text { phenomena }\end{array}$ \\
\hline & Elicit explanations & $\begin{array}{l}\text { Lesson asks students to give } \\
\text { explanations for their } \\
\text { ideas/predictions }\end{array}$ \\
\hline & Record and share ideas & $\begin{array}{l}\text { Lesson provides opportunities for } \\
\text { students' ideas to be recorded and } \\
\text { shared with others in the class }\end{array}$ \\
\hline \multirow[t]{3}{*}{$\begin{array}{l}\text { Providing } \\
\text { experiences with } \\
\text { phenomena }\end{array}$} & Multiple experiences & $\begin{array}{l}\text { Lesson provides multiple experiences } \\
\text { with phenomena-first- and } \\
\text { second-hand experiences }\end{array}$ \\
\hline & Data collection & $\begin{array}{l}\text { Lesson engages students in recording } \\
\text { their data or observations }\end{array}$ \\
\hline & Data analysis & $\begin{array}{l}\text { Lesson provides engages students in } \\
\text { sharing their results and looking for } \\
\text { patterns in the data }\end{array}$ \\
\hline \multirow[t]{3}{*}{$\begin{array}{l}\text { Promoting students' } \\
\text { sense-making }\end{array}$} & $\begin{array}{l}\text { Evidence-based } \\
\text { explanations }\end{array}$ & $\begin{array}{l}\text { Lesson provides students with the } \\
\text { opportunity to use evidence in } \\
\text { support of a claim }\end{array}$ \\
\hline & Discussion questions & $\begin{array}{l}\text { Lesson provides teachers with } \\
\text { questions to help students interpret } \\
\text { their experiences with phenomena }\end{array}$ \\
\hline & Revisiting of initial ideas & $\begin{array}{l}\text { Lesson provides opportunities for } \\
\text { students to revisit their initial ideas } \\
\text { and predictions }\end{array}$ \\
\hline $\begin{array}{l}\text { Assessing student } \\
\text { learning }\end{array}$ & $\begin{array}{l}\text { Assess content and } \\
\text { inquiry }\end{array}$ & $\begin{array}{l}\text { Lesson provides teachers with } \\
\text { assessments that allow them to } \\
\text { assess inquiry skills and science } \\
\text { ideas }\end{array}$ \\
\hline
\end{tabular}

(Continued) 


\section{TABLE 1}

Continued

\begin{tabular}{|c|c|c|}
\hline Code & Subcode & Example \\
\hline & Assess each student & $\begin{array}{l}\text { Lesson provides teachers with } \\
\text { assessments that allow each } \\
\text { student to demonstrate } \\
\text { understanding and skills }\end{array}$ \\
\hline & Application of ideas & $\begin{array}{l}\text { Lesson provides teachers with } \\
\text { assessments that require students } \\
\text { to apply their ideas to a new } \\
\text { task/situation }\end{array}$ \\
\hline \multirow[t]{3}{*}{$\begin{array}{l}\text { Making science } \\
\text { accessible for all } \\
\text { students }\end{array}$} & Attend to individuals & $\begin{array}{l}\text { Lesson helps preservice teacher } \\
\text { attend to the needs of individual } \\
\text { students in his or her classroom }\end{array}$ \\
\hline & $\begin{array}{l}\text { Make explicit } \\
\text { connections }\end{array}$ & $\begin{array}{l}\text { Lesson enables students to make } \\
\text { connections between scientific ideas } \\
\text { and their personal experiences }\end{array}$ \\
\hline & Make terms accessible & $\begin{array}{l}\text { Lesson helps teachers make } \\
\text { terminology accessible to all } \\
\text { students }\end{array}$ \\
\hline
\end{tabular}

For each data source, we averaged the scores across the preservice teachers for each criterion. We then conducted a repeated measures one-way analysis of variance (ANOVA) to determine whether there was any statistical difference in the mean scores across criteria for each assignment, followed by post hoc pairwise comparisons. For these ANOVAs (and all others used in this study), we used the Geisser-Greenhouse conservative $F$ test as a correction to guard against violations of the sphericity assumption, and we used the Bonferroni inequality to control for Type I error rate during follow-up comparisons. These comparisons illuminated potential differences in the preservice teachers' understanding of the reform-based criteria, shedding light on areas of strength and difficulty in applying different aspects of their PCK.

We calculated the frequency and percentage of preservice teachers who demonstrated an understanding of each indicator within the lesson plan analysis assignments and reflective teaching assignments. We then identified strengths in preservice teachers' application of the indicators by identifying which indicators were correctly addressed by roughly half or more of the preservice teachers in a given assignment. We also coded the data for evidence of alternative understandings of the criteria. We developed these codes from their analyses using open coding strategies (Strauss \& Corbin, 1998) and identified common codes among the preservice teachers for each criterion across and within each assignment. We then used Magnusson and colleagues' model of PCK for science teaching as a lens with which to identify common groups of codes across the preservice teachers. These analyses shed light on the common strengths and weaknesses underlying the preservice teachers' PCK.

We also performed a repeated measures one-way ANOVA across the pretest, lesson plan analysis assignment(s), and posttest for each criterion to determine whether there was any statistical difference in the mean scores across assignments. We then conducted follow-up pairwise comparisons. These comparisons provided insight into changes in the application of preservice teachers' PCK while experiencing the methods course. Examining changes in scores also shed light on how the preservice teachers' application of Criterion 3 changed as they practiced applying this criterion across all three lesson plan analysis assignments. 
To enhance the validity of the study, a second independent rater coded a subset of the data (10\%). We then calculated relative observed percent agreement and Cohen's kappa coefficient. Percent agreement between raters was $88 \%$, and the value for kappa was 0.76 , indicating substantial agreement. All disagreements were resolved through discussion.

\section{RESULTS}

This study examined preservice teachers' analyses of science lesson plans, providing insight into their ability to apply their PCK in curricular planning. Thus, the following results are a measure not simply of what preservice teachers know but how they apply what they know. The first section presents findings from the lesson plan analysis assignments and reflective teaching assignments about the strengths and limitations in preservice teachers' PCK when planning curriculum-based lessons using reform-based criteria. The second section discusses changes in knowledge over time as the preservice teachers use criteria in the analysis of lesson plans.

\section{Analyzing Science Lesson Plans Using Reform-Based Criteria}

In the lesson plan analysis assignments, the preservice teachers identified the strengths and weaknesses in science lesson plans using a set of reform-based criteria as scaffolds. They practiced applying each criterion only once across the three analyses, with one exception (i.e., Criterion 3). A repeated measures analysis revealed that the scores on these assignments differed significantly among the seven criteria (see Table 2 for $F$ values). Post

\section{TABLE 2}

\section{Mean Scores for Each Reform-Based Criterion in Lesson Plan Analysis Assignments and Reflective Teaching Assignments}

\begin{tabular}{|c|c|c|c|c|c|c|}
\hline \multirow[b]{2}{*}{ Criterion } & \multicolumn{2}{|c|}{ Lesson Plan Analyses } & \multicolumn{2}{|c|}{ RT Assignment $1^{a}$} & \multicolumn{2}{|c|}{ RT Assignment 2} \\
\hline & $M^{b}$ & $S D$ & $M$ & $S D$ & $M$ & $S D$ \\
\hline 1: Learning goals & 1.67 & 0.92 & 2.10 & 0.75 & 2.02 & 0.52 \\
\hline 2: Purpose & 1.96 & 0.86 & 2.00 & 0.51 & 2.19 & 0.76 \\
\hline 3: Eliciting ideas & $1.92^{c}$ & 0.83 & 1.58 & 0.69 & 1.29 & 0.71 \\
\hline 4: Phenomena & 2.46 & 0.66 & $\mathrm{n} / \mathrm{a}$ & $\mathrm{n} / \mathrm{a}$ & 1.13 & 1.15 \\
\hline 5: Sense-making & 2.04 & 0.91 & $\mathrm{n} / \mathrm{a}$ & $\mathrm{n} / \mathrm{a}$ & 1.08 & 1.02 \\
\hline 6: Assessment & 1.25 & 0.79 & $\mathrm{n} / \mathrm{a}$ & $\mathrm{n} / \mathrm{a}$ & 1.35 & 0.94 \\
\hline 7: Accessibility & 1.21 & 0.83 & $\mathrm{n} / \mathrm{a}$ & $\mathrm{n} / \mathrm{a}$ & 1.04 & 0.81 \\
\hline$d f$ & \multicolumn{2}{|c|}{$4.28,98.54$} & \multicolumn{2}{|c|}{$1.90,43.67$} & \multicolumn{2}{|c|}{$4.51,103.79$} \\
\hline$F$ value ${ }^{d}$ & \multicolumn{2}{|c|}{$8.61^{* * *}$} & \multicolumn{2}{|c|}{$5.03^{*}$} & \multicolumn{2}{|c|}{$10.01^{* * *}$} \\
\hline Partial eta squared & \multicolumn{2}{|c|}{0.27} & \multicolumn{2}{|c|}{0.18} & \multicolumn{2}{|c|}{0.30} \\
\hline
\end{tabular}

${ }^{a}$ The preservice teachers had only learned about the first three criteria when they completed the first RT assignment.

${ }^{b}$ Means represent average number of indicators addressed by each preservice teacher for each criterion; maximum score $=3.0$.

${ }^{c}$ Mean score for Criterion 3 is from lesson plan analysis assignment 1 to have a consistent comparison across criteria.

${ }^{d}$ Repeated measures one-way ANOVA, using the Geisser-Greenhouse conservative $F$ test. ANOVAs compare mean scores across the criteria within each assignment.

${ }^{*} p<.05,{ }^{* *} p<.01,{ }^{* * *} p<.001$. 
hoc comparisons revealed that the majority of preservice teachers demonstrated beginning levels of understanding of the criteria (mean scores between 1.5 and 2.0), and in some cases, a strong understanding of the criteria (mean scores greater than 2.0), with the exception of Criteria 6 and 7-"assessing student learning" and "making science accessible to all students" (see Table 2 for means).

The preservice teachers also completed two reflective teaching assignments, where they analyzed lessons that they would teach in their field placements. In these assignments, the preservice teachers identified the lesson's strengths and weaknesses using criteria as scaffolds but were free to choose the criteria. The preservice teachers tended to apply at least two reform-based criteria of three in their analysis (RT1: 2.13/3; RT2: 2.42/3). A repeated measures analysis revealed that the mean scores for both reflective teaching assignments differed significantly among the criteria across preservice teachers (see Table 2 for $F$ values). Follow-up comparisons showed that the majority of preservice teachers demonstrated a strong understanding (mean scores greater than 2.0) of Criteria 1 and 2 - "attending to learning goals" and "establishing a sense of purpose"—in comparison to the rest of the criteria (see Table 2). A qualitative description of the ways in which the preservice teachers applied their PCK in analyzing and improving curriculum-based lesson is provided below.

\section{Strengths in Preservice Teachers' PCK}

Across both types of assignments, the preservice teachers expressed consistent strengths in applying their knowledge of science curricula (Criterion 1) and strategies for establishing the purpose of a lesson (Criterion 2). In addition, in the lesson plan analysis assignments where the preservice teachers analyzed inquiry-oriented lesson plans provided by their course instructor, the preservice teachers demonstrated beginning knowledge of instructional strategies for engaging students in inquiry (Criteria 3-5). These strengths are described in detail below.

Knowledge of Science Curricula. Preservice teachers were asked to attend to learning goals (Criterion 1), one aspect of understanding science curricula (Magnusson et al., 1999). In doing so, most preservice teachers examined lesson activities to see if they helped students make progress toward the learning goals and made accurate judgments about alignment (LPA1: 22/24; RT1: 20/24; RT2: 22/24). Roughly one half of the preservice teachers also checked learning goals to make sure they addressed both science concepts and practices (LPA1: 10/24; RT1: 11/24). For example, in the first lesson plan analysis assignment, the lesson contained only content learning goals, leading some preservice teachers to incorporate inquiry learning goals to the lesson. Amelia illustrates this analysis:

The learning goals listed in the lesson plan address science content. The first goal asks students to identify one useful property of materials ... [and] the second goal asks students to classify objects according to a certain property ... However, the learning goals do not address inquiry... An appropriate inquiry learning goal would be "Students will construct charts of and summarize their findings for the purpose of communicating with others" ... [or] "Students communicate their findings with others using data charts." (LPA1)

These are some of the ways in which the preservice teachers used their knowledge of science learning goals to identify strengths and weaknesses within existing curriculum materials. 


\section{Knowledge of General Instructional Strategies for Teaching Science}

Instructional Strategies for Establishing the Purpose of the Lesson. Almost all of the preservice teachers understood the importance of making the lesson purpose explicit to students (Criterion 2) and successfully checked to make sure this feature was included in lessons (LPA1: 22/24; RT1: 21/24; RT2: 22/24). For example, in the first lesson plan analysis assignment, the preservice teachers recognized that the lesson purpose-to learn about a property of materials — was clearly communicated to students. Jessica wrote, "The opening question introduces the idea of waterproofing as the students think about how they can keep a cotton ball dry. Also, brainstorming ideas of how to keep something dry is a way to explicitly get students thinking."

The preservice teachers, though fewer of them, also made modifications to help students see the purpose as meaningful and anchored in their lives (LPA1: 14/24; RT2: 10/24). For example, in the first assignment, some preservice teachers recognized that the stated lesson purpose - to keep a cotton ball dry in the rain-was not likely to be meaningful to students' everyday lives. These individuals addressed this weakness by adding a more relevant investigation question to the beginning of the lesson, such as, "How can I stay dry when it is raining?" (Karen, LPA1).

Finally, sometimes the purpose of a lesson is never explicitly connected to previous lessons that students have experienced. At least half of the preservice teachers recognized that it is important to make these connections explicit and successfully analyzed lessons to determine how well they helped students see the coherent storyline of the unit (LPA1: 11/24; RT1: 22/24; RT2: 20/24). For example, in their first analysis, some of the preservice teachers recognized that the lesson plan did connect with what students had been learning about in class but did not help students see these connections. To address this weakness, they suggested adding a review session or teacher explanation to the beginning of the lesson to make these connections more explicit.

These examples illustrate some of the ways in which the preservice teachers applied their knowledge of science instructional strategies to establish the purpose of the lesson.

Instructional Strategies for Engaging Students in Scientific Inquiry. In their analysis of inquiry-oriented lesson plans within the lesson plan analysis assignments, the preservice teachers were asked to identify or add instructional strategies that engage students in scientific inquiry (Criteria 3-5). Over half of the preservice teachers successfully looked for opportunities to engage students in multiple experiences with phenomena, through first-hand or vicarious experiences (LPA2: 15/24). For example, in the second lesson plan analysis, Lisa added a second experience with the phenomenon of seed dispersal to help students see the concept as having explanatory power. She wrote,

This lesson revolves around one experience with phenomena: the hands-on experiment with seeds. If I were to change this lesson, I would integrate a video or images of seeds in motion in everyday settings (a bur on a dog, helicopters). Students are more likely to make connections to a phenomenon when they see it at play in its natural environment than in a lab (Oh! My dog gets burs in her fur... ). (LPA2)

Students also need opportunities to record, share, and interpret data. Most preservice teachers successfully analyzed lessons for such experiences, identifying or providing opportunities to record data (LPA2: 24/24) and look for patterns in it (LPA2: 20/24). Claire illustrates this in her adaptation of the seed dispersal lesson, writing, 
The lesson does not explicitly [ask] students to share their results ... Having each group share their results with the whole class might help the class look for patterns inherent across groups and help students test their conclusions against those of their classmates. (LPA2).

To help students make sense of data and the scientific ideas, two thirds of preservice teachers also examined lessons for opportunities to give explanations and link them to evidence (LPA2: 16/24). For example, in the seed dispersal lesson, the preservice teachers noted that the discussion at the end would enable students to use their investigation results to support claims about how seeds from their playground are dispersed.

These examples illustrate some of the ways that preservice teachers successfully identified or added strategies for supporting students in learning about science through inquiry.

\section{Limitations in Preservice Teachers' PCK}

In both the lesson plan analysis assignments and reflective teaching assignments, the preservice teachers also expressed a variety of alternative understandings of the criteria, illuminating particular weaknesses in their PCK. Specifically, the preservice teachers struggled with developing and applying their knowledge of science assessment (Criterion 6), their ideas about instructional strategies for making content accessible to all students (Criterion 7), and in some ways their knowledge of science curricula (Criteria 1 and 6). In the reflective teaching assignments where the preservice teachers analyzed lesson plans from their field placements, the preservice teachers also encountered challenges in applying their knowledge of instructional strategies for engaging students in inquiry (Criteria 3-5). The main alternative ideas expressed by the preservice teachers are enumerated in Table 3 and described in the sections below.

Knowledge of Science Assessment. The preservice teachers expressed alternative ideas about what and how to assess (Criterion 6) - both components within Magnusson and colleagues' (1999) model of PCK for science teaching. More than one third of the preservice teachers (LPA3: 10/24) tended to think about assessment exclusively in terms of students' content understandings rather than also in terms of students' inquiry abilities. With regard to methods of assessment, more than half of the preservice teachers (RT2: 14/24) did not adapt lessons to assess individual students' learning, in part, because they thought they could draw conclusions about such learning from assessments focused at the whole-class level (e.g., whole-class discussion). Roughly half of the preservice teachers (LPA3: 11/24) also assumed that science worksheets provided in curriculum materials always enable teachers to assess all aspects of student learning. For example, one of the lessons for analysis contained a worksheet that enabled the teacher to assess students' ability to make predictions and record results but not their ability to develop scientific explanations or express content understandings. However, Chelsea concluded, "In the best way that it could, I think that yes, this lesson does allow each student to demonstrate his or her understanding and [inquiry] skills. Each student is responsible for his or her own student notebook page" (LPA3). This example shows that some preservice teachers believed that having a worksheet in their lesson plan was sufficient for assessing all learning goals, resulting in missed opportunities to assess what students have learned from their investigations.

In addition, three fourths of the preservice teachers (RT2: 18/24) did not enable students in the lesson plans to apply their ideas to a new task or situation. This occurred because some 
TABLE 3 Main Alternative Understandings of the Reform-Based Criteria

\begin{tabular}{|c|c|c|c|c|}
\hline \multirow[b]{2}{*}{ Knowledge of. . . } & \multirow[b]{2}{*}{ Alternative Idea } & \multirow{2}{*}{$\begin{array}{l}\text { Criterion } \\
\text { Connection }\end{array}$} & \multicolumn{2}{|c|}{ Assignment $^{a}$} \\
\hline & & & LPA & $\mathrm{RT}$ \\
\hline \multirow[t]{4}{*}{$\begin{array}{l}\text { Science } \\
\text { assessment }\end{array}$} & $\begin{array}{l}\text { - Only content ideas need to be } \\
\text { assessed }\end{array}$ & 6 & $X$ & \\
\hline & $\begin{array}{l}\text { - Teachers do not need individual } \\
\text { assessments }\end{array}$ & 6 & & $X$ \\
\hline & $\begin{array}{l}\text { Worksheets allow teachers to } \\
\text { assess all goals }\end{array}$ & 6 & $\mathrm{X}$ & \\
\hline & $\begin{array}{l}\text { - Students apply their ideas to a } \\
\text { new task when doing a worksheet } \\
\text { for a reading/experiment }\end{array}$ & 6 & & $X$ \\
\hline \multirow[t]{2}{*}{ Science curricula } & $\begin{array}{l}\text { - Learning goals are always } \\
\text { connected to standards }\end{array}$ & 1 & $X$ & \\
\hline & $\begin{array}{l}\text { - Assessments are always } \\
\text { connected to goals }\end{array}$ & 6 & $X$ & $X$ \\
\hline \multirow{3}{*}{$\begin{array}{l}\text { Instructional } \\
\text { strategies for } \\
\text { making content } \\
\text { accessible to all } \\
\text { students }\end{array}$} & $\begin{array}{l}\text { - Students make connections on } \\
\text { their own between the content and } \\
\text { their lived experiences }\end{array}$ & 7 & & $X$ \\
\hline & $\begin{array}{l}\text { Providing students with definitions } \\
\text { makes science accessible to all } \\
\text { students }\end{array}$ & 7 & $X$ & \\
\hline & $\begin{array}{l}\text { - Teachers can help individual } \\
\text { students by focusing on the class } \\
\text { as a whole }\end{array}$ & 7 & $X$ & $X$ \\
\hline \multirow{3}{*}{$\begin{array}{l}\text { Instructional } \\
\text { strategies for } \\
\text { engaging } \\
\text { students in } \\
\text { scientific inquiry }\end{array}$} & $\begin{array}{l}\text { - Students' predictions about the } \\
\text { phenomena means eliciting their } \\
\text { prior knowledge }\end{array}$ & 3 & & $X$ \\
\hline & $\begin{array}{l}\text { - Providing multiple experiences } \\
\text { with phenomena means doing } \\
\text { different parts of one activity or } \\
\text { attending to different learning } \\
\text { styles }\end{array}$ & 4 & & $X$ \\
\hline & $\begin{array}{l}\text { - Students form evidence-based } \\
\text { explanations by sharing what they } \\
\text { learned or giving details }\end{array}$ & 5 & & $X$ \\
\hline
\end{tabular}

${ }^{a} X$ represents when roughly half or more of the preservice teachers exhibited an alternative understanding in a given assignment.

simply thought this meant having students apply what they had learned from a reading or experiment to complete a worksheet directly related to the activity (rather than to complete a new task). Debbie illustrated this alternative understanding, writing, "The properties the students observed would help them apply their newly acquired knowledge on liquids to their journal pages/grids about the bottles of liquids they had just investigated" (RT2). Failing to plan to give students a new task in which to apply their knowledge may result in missed opportunities to see if students can extend their ideas beyond the specific situation in which they were introduced. 
Knowledge of Science Curricula. The preservice teachers also expressed naive ideas about the design of curriculum materials. For example, two thirds (LPA1: 16/24) assumed learning goals are necessarily aligned with standards (Criterion 1), leading them not to check the standard documents for themselves. Chelsea exemplifies this idea, writing, "I feel that [the content learning goal] is well-aligned, since it fits well within the context of the unit as a whole (properties of matter), and I am assuming that the entire unit must be meeting some sort of state and/or local standards" (LPA1). Failing to check whether lessons actually help students make progress toward the standards may result in missed opportunities to address particular standards and thus promote student learning.

Other individuals (LPA1: 15/24; RT2: 16/24) assumed learning goals are automatically aligned with assessments (Criterion 6), leading them not to check for alignment between the two. For example, Kimberly included a handout and other assessments in her lesson plan to gauge student learning about instincts and learned behaviors but did not articulate connections between the assessments and the content understandings and inquiry abilities they were intended to measure. She wrote, "I will be collecting the handout to give me a formal understanding of what they learned. I will also be looking for informal assessments throughout the lesson to see who participates" (RT2). This excerpt provides a typical example showing that some preservice teachers thought that if a lesson simply includes an assessment, then they would need to do no further work to determine whether the assessment allows them to assess all relevant aspects of student learning. This alternative understanding may result in missed opportunities to assess some learning goals, limiting what they can discern about what students are able to understand and do.

\section{Knowledge of General Instructional Strategies for Teaching Science.}

Instructional Strategies for Making the Content Accessible to All Students. Several preservice teachers expressed naïve ideas about what it means to make science accessible to all students (Criterion 7). For example, with their own lesson plans, the majority of preservice teachers (RT2: 19/24) did not modify them to help students make connections between the scientific ideas and their personal, cultural, and/or social experiences. In addition, three fourths of the preservice teachers (LPA3: 18/24) thought that they could make science accessible to students if they simply provided definitions at the start of a lesson. This idea assumes that all students can develop an understanding of a particular concept simply by hearing a definition without grounding it in their lived experiences. Emily made this assertion, writing,

This lesson helps teachers make scientific terminology accessible to all students. At the beginning of the lesson ... [the teacher] tells them that friction is "a force (or pull) that allows down moving objects." In this way, she is making certain scientific terms available for all students in that she is reciting the definition to the whole class. (LPA3)

Assuming students learn science by memorizing definitions may limit sense-making opportunities for students as well as alienate those who are not familiar with the norms of scientific language.

The majority of preservice teachers (LPA3: 20/24; RT2: 17/24) also struggled with modifying lesson plans to accommodate the needs of individual students or groups of students. They tended to focus on strategies for helping students, in general-for example, by modeling how to do an experiment or circulating while students work independentlyrather than helping specific students. This point is illustrated in Lisa's analysis: "During the 
whole class modeling, I can circulate the room and address the needs of individuals while talking with the whole class at the same time" (RT2). Providing support within lesson plans only for the class as a whole rather than also for individual students may result in missed opportunities to differentiate instruction and thus help all students experience success in learning about science.

Instructional Strategies for Engaging Students in Scientific Inquiry. In their analysis of lesson plans from their field placements, the preservice teachers also demonstrated a limited understanding of how to foster an inquiry learning environment (Criteria 3-5). For example, most preservice teachers (RT1: 17/24; RT2: 19/24) did not adapt lessons to engage students in making predictions during their investigations (Criterion 3), in part, because they misunderstood this inquiry practice to mean eliciting prior knowledge about a topic rather than eliciting ideas about the possible outcome of an investigation.

The majority of preservice teachers (RT2: 17/24) also did not provide students with multiple experiences with phenomena (Criterion 4). Some misinterpreted this inquiry feature to mean having students experience different components of a lesson-for example, completing a worksheet, engaging in a hands-on activity, and participating in discussions. For example, Mia pointed to different components of one experience as evidence that the lesson plan provided students with multiple experiences. She wrote, "We are going to use resources from the book, and on the internet, to find out different facts and characteristics about the [Mississippi] river" (RT2). Mia provided her students with only one way to learn about rivers in her lesson, resulting in a missed opportunity to engage students in a different experience with the phenomenon such as an outdoor exploration of a nearby river or observations of a watershed using a stream table.

On the other hand, some preservice teachers thought providing multiple experiences with phenomenon meant having students experience different learning styles (e.g., auditory, visual, kinesthetic). Leah illustrated this alternative understanding, writing, "[My students] learn best by hearing, seeing, and experimenting with new/old information. The information will be written on the overhead, myself and the students will verbally say it, and we will test it with our experiment" (RT1). Like Shelley, Leah's alternative understanding resulted in students only having one chance to learn about a particular concept. Failing to understand what counts as an experience with scientific phenomena may result in missed opportunities for students to learn about a concept in multiple contexts, and in turn, see science ideas as having explanatory power.

Many preservice teachers (RT2: 18/24) also struggled with adapting their own lessons to help students give explanations and link them to evidence (Criterion 5). In their lesson plans, some preservice teachers simply asked students to form a detailed response when giving an evidence-based explanation. Thus, having students "tell," "describe," or "explain" were viewed as synonymous terms. Others conceptualized an evidence-based explanation more broadly, defining it as an oral response about what students had learned. For example, Carmen ended her lesson on rain, writing, "My students will construct explanations about what they have learned when I ask students, 'What have you learned today? Can you tell me one thing?"' (RT2). Preservice teachers, like Carmen, assumed that sharing ideas in discussion either was the same thing as providing evidence-based explanations or would necessarily lead students to give evidence for their explanations. In either case, these alternative understandings de-emphasize the role of evidence in the classroom. Not holding students accountable for providing evidence for their ideas may prevent students from learning how to support their ideas and making connections between scientific ideas and their explorations. 


\section{Changes Over Time in Preservice Teachers' PCK}

Looking at mean scores across the pretest, lesson plan analysis assignment(s), and posttest, a repeated measures one-way ANOVA revealed significant differences in assignment scores for each criterion (see Table 4 for $F$ values). For all of the criteria (except Criterion 3), the preservice teachers scored significantly higher on the lesson plan analysis assignments and posttest, in comparison to the pretest. However, posttest scores were significantly lower than the scores on the lesson plan analysis assignment (see Table 4 for means). These results show after learning about reform-based criteria and using them to analyze lessons, the preservice teachers displayed greater strengths in improving lessons to address the goals of reform-based science teaching. However, they were not as successful in applying their PCK in an open-ended analysis task, when scaffolds were removed, in comparison to the lesson plan analysis assignments.

As for Criterion 3-the criterion applied across all three lesson plan analysis assignments - the preservice teachers scored significantly higher on the first and third lesson plan analysis assignments and posttest, in comparison to the pretest and second lesson plan analysis assignment. All other post hoc comparisons for Criterion 3 were insignificant (see Table 4 for means). These results show that after learning about instructional strategies for eliciting students' ideas, the preservice teachers demonstrated an improved understanding of this aspect of PCK in the first lesson plan analysis assignment, in comparison to the pretest, but struggled to apply their knowledge in the second assignment. However, after analyzing two different lesson plans and receiving feedback on their ideas, the preservice teachers demonstrated a strong understanding of this aspect of PCK in the third assignment and continued to do so in the posttest analysis when scaffolds were removed.

In comparing scores across the seven reform-based criteria, a repeated measures analysis, with follow-up comparisons, revealed negligible differences in the pretest scores (see Table 4 for $F$ values). The preservice teachers tended to demonstrate a limited understanding across all aspects of PCK at the beginning of the course (see Table 4 for means). However, by the end of the course, a repeated measures analysis revealed that posttest scores were significantly different among the criteria (see Table 4 for $F$ values). Post hoc comparisons showed that the preservice teachers demonstrated a significantly stronger understanding of Criterion 3 by the end of the course than the other reform-based criteria (see Table 4 for means). A qualitative description of these results is presented below.

\section{Analyzing Multiple Science Lesson Plans Using the Same Reform-Based Criterion}

In the pretests, only half of the preservice teachers mentioned ideas related to Criterion 3-“eliciting students' prior knowledge and predictions." When they did attend to this criterion, the preservice teachers mentioned only one strength or weakness and focused on students' prior knowledge, not their predictions. A typical response is exemplified in Mia's analysis: "I liked the use of the question at the beginning of the activity 'What is insulation?' It makes the kids think and come up with their own ideas before they dig into the lesson" (Pretest).

During the course, the preservice teachers participated in class activities, readings, and discussions to develop their knowledge of instructional strategies for eliciting students' ideas and then applied their knowledge in the analysis of a science lesson plan (LPA1). Two thirds of the preservice teachers (16/24) successfully applied Criterion 3 in the first assignment. Among other things, they recognized that the lesson provided opportunities to 


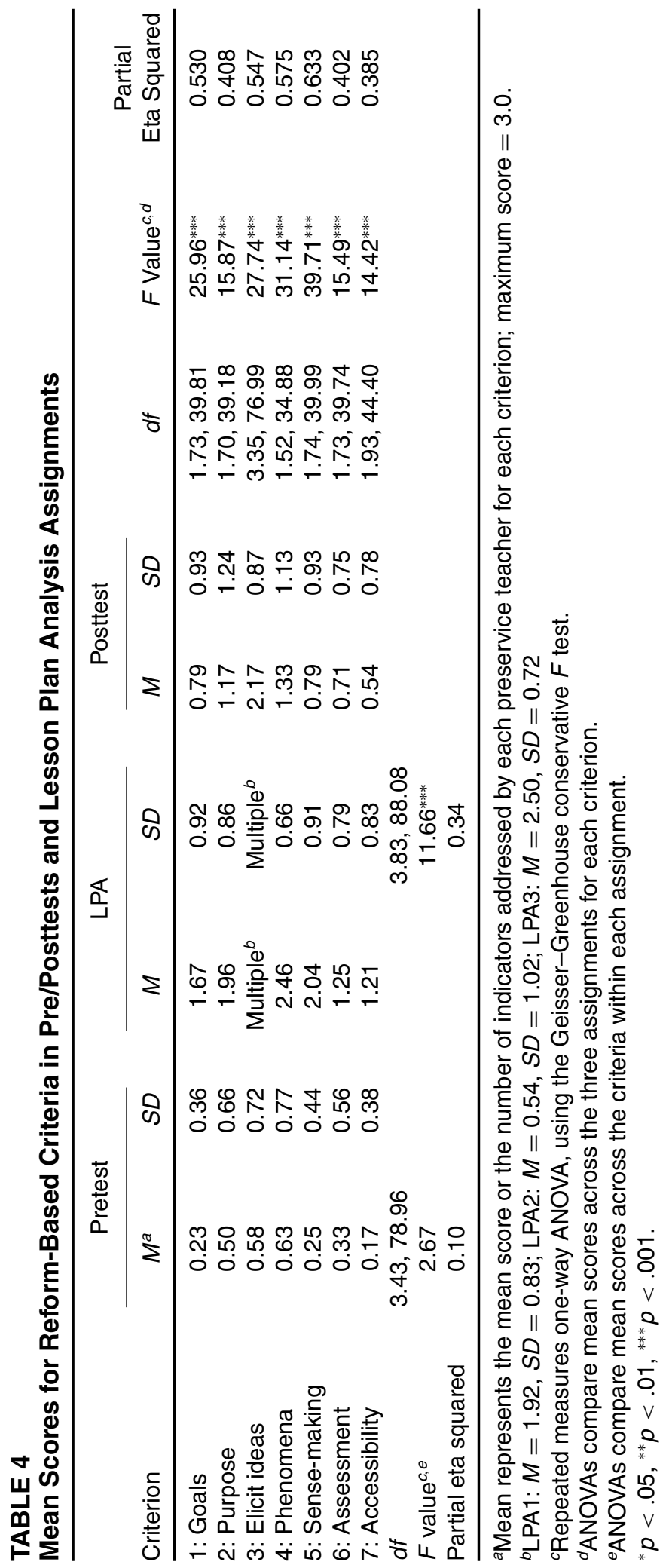

Science Education, Vol. 96, No. 1, pp. 130-157 (2012) 
elicit students' prior knowledge about the content and predictions about the phenomena, as seen in Lisa's analysis:

Students are given the opportunity to reflect on their ideas before the lesson begins when they are asked to draw a picture of how one could protect a cotton ball in the rain. In addition, they are given a space in which to record their predictions regarding whether each material being tested in the investigation will be waterproof or not. (LPA1)

Therefore, in the first assignment, it appeared that most of the preservice teachers had a strong understanding of instructional strategies for eliciting students' prior knowledge and predictions.

In the second lesson plan analysis assignment, the lesson plan contained different strengths and weaknesses from the lesson in the first assignment. One difference was that the second lesson plan did not provide an opportunity for students to make predictions. Only five preservice teachers identified this omission in the lesson plan. For example, Melanie wrote,

[The students] are directed to draw [seeds] and record their names, but there isn't a time where they predict how they disperse based on their characteristics. I would change this part by having the students observe the seeds they are given, then make a prediction of how they travel either by wind, water, or animal (hitchhiker), and then have them explain why they chose that option. (LPA2)

The rest of the class (19/24) did not recognize that the lesson failed to elicit students' predictions because they had an alternative understanding of what a prediction is. These preservice teachers viewed students' predictions about the phenomena as the same thing as prior knowledge about the new topic. As a result, these individuals mistakenly asserted that the lesson plan elicited both students' initials ideas and predictions, as illustrated in Debbie's analysis:

The two questions that the teacher asks about where new plants grow and why new plants do not grow under a parent plant allows the teacher to elicit further ideas about the new content, as well as having students make predictions during this discussion. (LPA2)

This typical example shows that most of the preservice teachers did not view predictions as dealing specifically with students' ideas about what they think the results from an investigation will be. Thus, the second assignment enabled the preservice teachers to uncover limitations in their understandings not revealed in the first assignment.

Like the first two lesson plans, the lesson plan for the third assignment also emphasized different strengths and weaknesses with regard to Criterion 3. The lesson contained questions to elicit students' prior knowledge about the content and predictions about the phenomena. All but three preservice teachers (21/24) identified these questions, as seen in Ashley's analysis:

The teacher does elicit students' ideas about the new content (Friction). In the getting started section of the lesson plan the teacher writes the word "friction" on the boards and asks students to share what they think the word might mean. After they come up with ideas the teacher tells them what friction is. She allows the students to feel the three different surfaces they will be using in their experiment and has them make predictions about on which surface the toy car will travel the longest distance and the shortest distance. This allows students to make predictions about the phenomena. (LPA3) 
The third lesson plan also asked students to give explanations for their predictions but not for their initial ideas and enabled students to share their prior knowledge with peers but not their predictions. Because most preservice teachers were by this time able to differentiate between eliciting students' prior knowledge and predictions, they were able to make productive adaptations that enabled students to give explanations for their initial ideas (18/24) and share their predictions with peers (20/24). Therefore, after applying the same criterion across three scaffolded analysis tasks, the majority of the preservice teachers demonstrated strong application of Criterion 3. Specifically, they accurately identified and/or created separate opportunities to elicit both students' prior knowledge and predictions about the phenomenon. Their PCK improved with repeated opportunities to apply their knowledge in analyzing science lesson plans.

In the posttests (when scaffolds were no longer in place), all of the preservice teachers mentioned ideas related to Criterion 3. In addition, their analyses typically addressed multiple dimensions ( $3+$ ) of this aspect of PCK, including a focus on eliciting both students' prior knowledge and predictions. Kylie provided a typical response:

This lesson does a good job of eliciting student ideas. The students are asked to share and explain their ideas about insulation with the entire class. Then they share their ideas about which container they could use to best "insulate" their ice cube. However, they do not explain their reasons for why they made their choices or make any records. (Posttest)

Here, Kylie looked for opportunities to elicit students' predictions, in addition to their prior knowledge about the content, and identified ways to improve these strategies during the lesson. These results show that after having repeated opportunities to practice applying their ideas, the preservice teachers recognized that eliciting students' prior knowledge and predictions is an important aspect of science teaching and used their newly developed PCK to create and adapt strategies for eliciting students' ideas within an open-ended analysis task.

\section{DISCUSSION AND IMPLICATIONS}

Curriculum materials play a fundamental role in shaping classroom instruction, helping teachers make thoughtful decisions about practice. Effective teachers use curriculum materials as a guide, critiquing and adapting them to compensate for their weaknesses and address specific student needs and circumstances (Barab \& Luehmann, 2003; Brown, 2009). Even though analyzing lessons is an essential aspect of teaching practice, preservice teachers encounter many difficulties in doing so (Beyer \& Davis, 2009; Davis, 2006; Schwarz et al., 2008). To support preservice elementary teachers in developing beginning levels of proficiency in critiquing and adapting science curriculum materials, this study focused on the use of a criterion-based approach to analysis and the use of reform-based criteria, specifically. The study's participants learned about these criteria through readings and in-class activities and applied the criteria in their analysis of lesson plans from their course instructor and field placements. By scaffolding the use of reform-based criteria, we aimed to support preservice teachers in developing and applying their PCK in the analysis of science curriculum materials.

\section{Theoretical Insights Into Science Teacher Knowledge}

Strengths in Preservice Teachers' PCK. In developing their capacity for curricular planning, the preservice teachers demonstrated some strengths in their PCK. In applying their

Science Education, Vol. 96, No. 1, pp. 130-157 (2012) 
knowledge of science curriculum (Criterion 1), the preservice teachers designed learning goals that aligned with lesson activities and attended to both science topics and scientific inquiry practices. The preservice teachers also demonstrated knowledge of instructional strategies for establishing a sense of purpose within a lesson (Criterion 2). They adapted lesson plans to anchor the lesson purpose in the lives of learners and help students make connections to previous lessons.

These outcomes may have resulted for a combination of reasons. First, the majority of preservice teachers may have made productive adaptations dealing with learning goals and lesson purpose because they had practice attending to these two features of lesson plans in previous courses during their first year in the teacher education program. For example, in an interview, Shelley shared, "We did a lot in the social studies methods course. We listed the [learning goals] pretty much in every class." In addition to prior knowledge, the preservice teachers learned about these criteria at the beginning of the course, providing them with the opportunity to engage in additional practice in applying them in their analysis of lesson plans during the course, particularly, in their analysis of lessons from their field placements. Third, the intended meanings of the criteria may have been accessible to the preservice teachers. The language within and the conceptual ideas underlying these criteria may have been clearly articulated and unpacked and may have been consistent with the preservice teachers' own goals and understandings of science teaching. Others have identified this as an important factor in helping preservice teachers successfully apply their PCK in the analysis of lesson plans (Davis, 2006; Schwarz et al., 2008).

Limitations in Preservice Teachers' PCK. Even though the preservice teachers demonstrated strengths in applying some aspects of their PCK, they also exhibited a number of alternative ideas. Expanding upon other studies that have identified limitations in preservice and new teachers' science PCK (e.g., Abell \& Roth, 1992; van Driel et al., 1998; ZembalSaul et al., 2002), this study highlights additional alternative ideas that novice teachers may have as they apply their knowledge of science assessment, science curriculum materials, and science instructional strategies, as described below.

In this study, the preservice teachers expressed alternative ideas about science assessment. For example, in their adaptation of lesson plans, some of the preservice teachers focused only on assessment of conceptual ideas (not inquiry abilities), the use of worksheets to assess learning goals, and group assessments for making claims about individual student learning. These findings may have occurred, in part, because the preservice teachers held a more traditional view of assessment, which emphasizes assessment of scientific knowledge at the exclusion of assessing scientific understanding and reasoning (NRC, 1996). Another explanation for these findings is that the preservice teachers may not have spent much time thinking about learners and learning. New teachers tend to focus on themselves as teachers, developing their knowledge and skills for teaching at the exclusion of thinking about how to assess and respond to learners (Fuller, 1969; Furlong \& Maynard, 1995; LaBoskey, 1994). As a result, the preservice teachers in this study may have engaged in more thoughtful planning about what they would teach rather than about what they wanted their students to learn and how they would measure it.

The preservice teachers also expressed limitations in their knowledge of science curricula-specifically, about the design of curriculum materials. For example, some assumed that learning goals are necessarily connected to standards and that assessments are automatically aligned with learning goals. One explanation for these assumptions is that the preservice teachers may have taken the curriculum materials as a given. They may have assumed, like other beginning teachers, that experts developed the curriculum materials 
(Ben-Peretz, 1990; Bullough, 1992; Schwarz et al., 2008) or that the curriculum materials were of high quality because they were published (Ball \& Feiman-Nemser, 1988; Ben-Peretz, 1990).

The preservice teachers also showed weaknesses in their knowledge of instructional strategies for making science content accessible to all students. For example, some individuals assumed that students automatically make connections between scientific ideas and their cultural, personal, and social experiences. Others assumed that simply providing students with a list of terms and definitions was a strategy for making the content accessible to all students. In addition, some preservice teachers believed it was sufficient to use wholeclass strategies (e.g., modeling a task, circulating among students) to address the needs of individual students or groups of students in their classroom. One explanation for these findings is the preservice teachers may have held naïve ideas about students and student learning (Southerland \& Gess-Newsome, 1999; Zembal-Saul et al., 2002), limiting their knowledge of instructional strategies for helping students learn science. Another possible explanation is that the preservice teachers may not have considered individual students' backgrounds, strengths, and needs in their curricular planning. Curriculum materials are typically designed for a wide audience and general context, leading teachers to make local adaptations for their specific classrooms (Barab \& Luehmann, 2003; Brown, 2009; Enyedy \& Goldberg, 2004; Pintó, 2004; Squire et al., 2003). However, the generality of the lesson plans may have led the preservice teachers to consider only adaptations for a class as a whole, masking the need to consider specific students as well.

Finally, preservice teachers expressed limitations in their knowledge of instructional strategies for engaging students in scientific inquiry. This was due, in part, to their undeveloped ideas about scientific inquiry. Like other studies (e.g., Beyer \& Davis, 2008; Haefner \& Zembal-Saul, 2004), this study found that the preservice teachers struggled with understanding what it means to construct an evidence-based explanation, and in turn, how to support students as they engage in this scientific practice. This study also highlighted alternative ideas about other aspects of scientific inquiry, including what it means to make a prediction and engage in experiences with phenomena. These alternative ideas may have occurred due to difficulties in discerning the intended meanings of these scientific practices and in understanding how the terms used to describe these practices were similar to and different from their vernacular uses of these terms.

\section{Design Implications for Science Teacher Education}

Using Reform-Based Criteria to Analyze Lesson Plans. This study provided preservice teachers with the opportunity to learn about and use reform-based criteria in curricular planning. After participating in these experiences, the preservice teachers displayed greater strengths from pre to post in applying their PCK to improve science lesson plans. Like other research studies (Beyer \& Davis, 2009; Davis, 2006; Lloyd \& Behm, 2005; Nicol \& Crespo, 2006; Schwarz et al., 2008), this study shows that with support, novice teachers are able to develop and apply their PCK to the task of curriculum materials analysis. In particular, preservice teachers may benefit from scaffolds that prompt the use of a criterion-based approach to analysis and the use of reform-based criteria, specifically.

Previous reports have found that having preservice teachers apply criteria only once within a scaffolded task results in mixed success with developing an understanding of the pedagogical ideas underlying the criteria (Schwarz et al., 2008) and in limited long-term changes in their ability to improve lesson plans (Beyer \& Davis, 2009). Therefore, the preservice teachers in the study had the opportunity to apply one of the criteria in multiple lesson plan analyses. As a result, the preservice teachers improved in their ability to apply 
this aspect of PCK, and by the posttest, demonstrate a stronger understanding of this knowledge component, in comparison to the other dimensions of PCK. This study provides evidence for the idea that preservice teachers are able to enhance their knowledge base when provided with multiple opportunities to practice applying the same criteria. Analyzing lesson plans that have different affordances and constraints with regard to particular criteria may enable novice teachers to visualize criteria in different ways. This, in turn, may enable them to develop their capacity to apply their PCK in planning curriculum-based lessons. This finding is consistent with the perspective that the fading of scaffolds needs to be synchronized with the gradual development of learners' understanding rather than abruptly removed before learners are ready to complete a task on their own (Collins et al., 1989; Pea, 2004). Thus, novice teachers may need to apply the same criteria within multiple contexts before having the scaffolds faded.

Targeting Limitations in Preservice Teachers' PCK. This study also highlights particular areas, described above, where teacher educators might work with novice teachers to help them identify and address specific gaps and limitations in their knowledge. These areas include preservice teachers' understanding of science assessment, science curricula, subject-specific instructional strategies, learners and learning, and scientific inquiry. Targeting these areas of weakness may help novice teachers develop greater capacities in applying their PCK in the analysis of science lesson plans. In turn, they may be better positioned to identify the strengths and weaknesses within curriculum-based lessons and make modifications that meet the ambitious goals entailed in reform-oriented science teaching.

In particular, the preservice teachers in this study struggled with adapting lesson plans to attend to the needs of individual learners. In planning lessons for students in their field placements, preservice teachers may benefit from prompts to think about the backgrounds, strengths, and needs of specific learners in their classroom and ways to adapt the lesson to personalize instruction for students. In analyzing instructor-provided lessons not grounded within a particular context, preservice teachers may benefit from case scenarios that describe a fictional classroom setting. Such scenarios may remind preservice teachers to think about a classroom as a set of individuals as they consider ways to critique and adapt lesson plans.

Providing Additional Support for Engaging in Authentic Analysis Experiences. In this study, the preservice teachers analyzed and taught lesson plans from their field placements. They demonstrated greater challenges in analyzing their own lesson plans, in comparison to the instructor-provided lesson plans. One explanation for this difference is that some of the scaffolds were removed from the reflective teaching assignments, allowing the preservice teachers to choose the criteria. As a result, some preservice teachers did not attend (at least explicitly) to some aspects of reform-based science instruction in their analysis. When preservice teachers did attend to the reform-based criteria, some expressed greater challenges in applying their PCK, in comparison to their analysis of instructorprovided lesson plans. This occurred, in part, because their own lesson plans, like many other existing science curriculum materials (Beyer et al., 2009; Hubisz, 2003; Kesidou \& Roseman, 2002; Stern \& Roseman, 2004), were poorly aligned with reform-based standards and practices and thus reflected additional weaknesses (Forbes \& Davis, 2010). Thus, analyzing science lesson plans from their field placements may have been a more challenging task than analyzing inquiry-oriented science lesson plans with particular elements provided by their course instructor.

These findings extend our understanding about how to support preservice teachers in transferring their knowledge and practices for curricular planning from in-class analysis 
assignments to more authentic analysis experiences. First, previous research has shown that the degree to which preservice teachers use particular criteria depends on whether the analysis task explicitly scaffolds their use or not (Davis, 2006). For example, Davis (2006) found that providing preservice teachers with a list of criteria representing complex ideas about science teaching enabled the preservice teachers to apply criteria not prominent in their own analysis ideas and thus engage in a more substantive analysis. This study corroborates this finding, showing that the preservice teachers did not necessarily attend to the newly learned criteria in the absence of explicit reminders to do so in their analysis assignments. Second, this study extends existing research by providing insights into how preservice teachers use what they have learned from in-class analysis tasks to plan lessons for their own students. The preservice teachers demonstrated some strengths in analyzing the inquiry-oriented lesson plans from the methods course but struggled to improve their own lesson plans-lesson plans that tended to be poorly aligned with reform-based science teaching (Forbes \& Davis, 2010). Similarly, Forbes and Davis found that a key factor impacting preservice teachers' ability to develop inquiry-oriented lesson plans was whether they started with quality curriculum materials or not.

Both of these findings support the argument that supports for preservice teachers need to be faded gradually as individuals are able to complete increasingly more complex aspects of the task on their own (Collins et al., 1989; Pea, 2004). In particular, preservice teachers may need additional reminders to consider particular criteria in their analysis before giving them free choice in their criteria selections. They may also need opportunities to practice analyzing low-quality science lesson plans together as a class, in addition to high-quality lesson plans, before analyzing lesson plans from their field placements on their own.

\section{Research Implications for Science Education}

Lesson Plan Analyses as a Tool to Document PCK. This study characterized preservice elementary teachers' PCK in critiquing and adapting science curriculum materials. These practice-based teaching tasks offer a novel approach to documenting PCK in practice that other researchers might use in their own investigations of PCK. Examining teachers' curricular planning practices, in general, may shed light on the types of knowledge that teachers draw upon in their planning and the ways in which they apply this knowledge. In particular, this teaching task may provide insight into the extent to which teachers are able to apply their PCK in ways that improve lesson plans. In addition, examining teachers' planning practices through the use of structured lesson plan analyses, like the ones in this study, may shed light on teachers' ability to apply particular aspects of their PCK-aspects of their knowledge that they might not otherwise consider on their own. Finally, engaging teachers in both structured and open-ended tasks together may provide insight into the extent to which teachers appropriate ideas learned from structured analysis tasks and use them in productive ways to plan instruction for their own students.

Future Research Directions. This study characterized preservice elementary teachers' capacity to apply their PCK in the analysis of science curriculum materials. These descriptions shed light on strengths in their understandings, areas in need of support, and benefits and limitations of using reform-based criteria as scaffolds. However, it is important to note that the findings and recommendations from this study are based on only one science methods course. Additional studies situated within other methods courses are needed to understand how the findings from this study extend to other preservice teachers and to increase the reliability of the recommendations proposed. Conducting additional studies 
within different contexts is also likely to lead to the identification of additional struggles preservice teachers face in developing their PCK and applying their understandings in the analysis of science curriculum materials. In addition, other leverage points and instructional strategies may also be elucidated for supporting preservice teachers' knowledge development.

\section{REFERENCES}

Abell, S. K. (2007). Research on science teacher knowledge. In S. K. Abell \& N. G. Lederman (Eds.), Handbook of research on science education (pp. 1105-1149). Mahwah, NJ: Erlbaum.

Abell, S. K., \& Roth, M. (1992). Constraints to teaching elementary science: A case study of a science enthusiast student teacher. Science Education, 76, 581-595.

Ball, D. L., \& Bass, H. (2000). Interweaving content and pedagogy in teaching and learning to teach: Knowing and using mathematics. In J. Boaler (Ed.), Multiple perspectives on the teaching and learning of mathematics. Westport, CT: Ablex.

Ball, D. L., \& Cohen, D. K. (1996). Reform by the book: What is-or might be-the role of curriculum materials in teacher learning and instructional reform? Educational Researcher, 25(9), 6-8, 14.

Ball, D. L., \& Feiman-Nemser, S. (1988). Using textbooks and teachers' guides: A dilemma for beginning teachers and teacher educators. Curriculum Inquiry, 18(4), 401-423.

Barab, S. A., \& Luehmann, A. L. (2003). Building sustainable science curriculum: Acknowledging and accommodating local adaptation. Science Education, 87(4), 454-467.

Ben-Peretz, M. (1990). The teacher-curriculum encounter: Freeing teachers from the tyranny of texts. Albany: State University New York Press.

Beyer, C. J., \& Davis, E. A. (2008). Fostering second graders' scientific explanations: A beginning elementary teacher's knowledge, beliefs, and practice. Journal of the Learning Sciences, 17, 381-414.

Beyer, C. J., \& Davis, E. A. (2009). Supporting preservice elementary teachers' critique and adaptation of science curriculum materials using educative curriculum materials. Journal of Science Teacher Education, 20(6), 517536.

Beyer, C. J., Delgado, C., Davis, E. A., \& Krajcik, J. S. (2009). Investigating teacher learning supports in high school biology textbooks to inform the design of educative curriculum materials. Journal of Research in Science Teaching, 46(9), 977-998.

Brown, M. W. (2009). The teacher-tool relationship: Theorizing the design and use of curriculum materials. In J. T. Remillard, B. A. Herbel-Eisenmann, \& G. M. Lloyd (Eds.), Mathematics teachers at work: Connecting curriculum materials and classroom instruction (pp. 17-36). New York: Routledge.

Bullough, R. V. J. (1992). Beginning teacher curriculum decision making, personal teaching metaphors, and teacher education. Teaching \& Teacher Education, 8(3), 239-252.

Cohen, D. K., \& Ball, D. L. (1999). Instruction, capacity, and improvement (CPRE Research Report Series RR-043). Philadelphia: University of Pennsylvania Consortium for Policy Research in Education.

Collin, A., Brown, J. S., \& Newman, S. E. (1989). Cognitive apprenticeship: Teaching the craft of reading, writing, and mathematics. In L B. Resnick (Ed.), Knowing, learning, and instruction: Essays in honor of Robert Glaser (pp. 453-494). Hillsdale, NJ: Erlbaum.

Collopy, R. (2003). Curriculum materials as a professional development tool: How a mathematics textbook affected two teachers' learning. The Elementary School Journal, 103(3), 227-311.

Davis, E. A. (2006). Preservice elementary teachers' critique of instructional materials for science. Science Education, 90(2): 348-375.

Davis, E. A., \& Krajcik, J. (2005). Designing educative curriculum materials to promote teacher learning. Educational Researcher, 34(3), 3-14.

Davis, E. A, \& Smithey, J. (2009). Beginners moving toward effective elementary science teaching. Science Education, 93(4), 745-770.

Drake, C., \& Sherin, M. G. (2009). Developing curriculum vision and trust: Changes in teachers' curriculum strategies. In J. T. Remillard, B. A. Herbel-Eisenmann, \& G. M. Lloyd (Eds.), Mathematics teachers at work: Connecting curriculum materials and classroom instruction (pp. 321-337). New York: Routledge.

Enyedy, N., \& Goldberg, J. (2004). Inquiry in interaction: How local adaptations of curricula shape classroom communities. Journal of Research in Science Teaching, 41(9), 905-935.

Forbes, C. T., \& Davis, E. A. (2010). Curriculum design for inquiry: Preservice elementary teachers' mobilization and adaptation of science curriculum materials. Journal of Research in Science Teaching, 47(7), 820-839.

Fuller, F. (1969). Concerns of teachers: A developmental conceptualization. American Educational Research Journal, 6, 207-226. 
Furlong, J., \& Maynard, T. (1995). Mentoring student teachers-The growth of professional knowledge. London: Routledge.

Grossman, P. (1990). The making of a teacher: Teacher knowledge and teacher education. New York: Teachers College Press.

Grossman, P., Compton, C., Igra, D., Ronfeldt, M., Shahan, E., \& Williamson, P. (2009). Teaching practice: A cross-professional perspective. Teachers College Record, 111(9), 2055-2100.

Grossman, P., \& Thompson, C. (2008). Learning from curriculum materials: Scaffolds for new teachers? Teaching and Teacher Education, 24(8), 2014-2026.

Haefner, L. A., \& Zembal-Saul, C. (2004). Learning by doing? Prospective elementary teachers' developing understandings of scientific inquiry and science teaching and learning. International Journal of Science Education, 26(3), $1653-1674$.

Hill, H. C., \& Ball, D. L. (2008). Unpacking pedagogical content knowledge: Conceptualizing and measuring teachers' topic-specific knowledge of students. Journal for Research in Mathematics Education, 39(4), $372-$ 400 .

Hogan, K., \& Pressley, M. (1997). Scaffolding student learning: Instructional approaches and issues. Cambridge, MA: Brookline Books.

Hubisz, J. (2003). Middle-school texts don't make the grade. Physics Today, 56(5). Retrieved August 1, 2011, from www.science-house.org/middleschool/whatsnew/Pt-Hubisz05031.pdf.

Kesidou, S., \& Roseman, J. E. (2002). How well do middle school science programs measure up? Findings from Project 2061's curriculum review. Journal of Research in Science Teaching, 39(6), 522-549.

LaBoskey, V. (1994). Development of reflective practice: A study of preservice teachers. New York: Teachers College Press.

Lloyd, G. M., \& Behm, S. L. (2005). Preservice elementary teachers' analysis of mathematics instructional materials. Action in Teacher Education, 26(4), 48-62.

Magnusson, S., Krajcik, J., \& Borko, H. (1999). Nature, sources, and development of pedagogical content knowledge for science teaching. In J. Gess-Newsome \& N. Lederman (Eds.), Examining pedagogical content knowledge: The construct and its implications for science education (pp. 95-132). Dordrecht, The Netherlands: Kluwer.

National Center for Education Statistics. (2007). Digest of education statistics, 2007. Retrieved July 22, 2008, from http://nces.ed.gov/programs/digest/d07/.

National Research Council. (1996). National Science Education Standards. Washington, DC: National Academy Press.

Nicol, C. C., \& Crespo, S. M. (2006). Learning to teach with mathematics textbooks: How preservice teachers interpret and use curriculum materials. Educational Studies in Mathematics, 62, 331-355.

Pea, R. (2004). The social and technological dimensions of scaffolding and related theoretical concepts for learning, education, and human activity. Journal of the Learning Sciences, 13(3), 423-451.

Pintó, R. (2004). Introducing curriculum innovations in science: Identifying teachers' transformations and the design of related teacher education. Science Education, 89, 1-12.

Remillard, J. T. (1999). Curriculum materials in mathematics education reform: A framework for examining teachers' curriculum development. Curriculum Inquiry, 19(3), 315-342.

Remillard, J. T. (2005). Examining key concepts in research on teachers' use of mathematics curricula. Review of Educational Research, 75(2), 211-246.

Schwarz, C., Gunckel, K., Smith, E., Covitt, B., Bae, M., Enfield, M., et al. (2008). Helping elementary pre-service teachers learn to use science curriculum materials for effective science teaching. Science Education, 92(2), $345-377$.

Shulman, L. S. (1986). Those who understand: Knowledge growth in teaching. Educational Researcher, 15(2), $4-14$.

Southerland, S., \& Gess-Newsome, J. (1999). Preservice teachers' views of inclusive science teaching as shaped by images of teaching, learning, and knowledge. Science Education, 83(2), 131-150.

Squire, K. D., MaKinster, J. G., Barnett, M., Luehmann, A. L., \& Barab, S. L. (2003). Designed curriculum and local culture: Acknowledging the primacy of classroom culture. Science Education, 87(4), 468489.

Stern, L., \& Roseman, J. E. (2004). Can middle-school science textbooks help students learn important ideas? Findings from Project 2061's curriculum evaluation study: Life science. Journal of Research in Science Teaching, 41(6), 538-568.

Stone, C. A. (1993). What is missing in the metaphor of scaffolding? In E. A. Forman, N. Minick, \& C. A. Stone (Eds.), Contexts for learning: Sociocultural dynamics in children's development (pp. 169-183). New York: Oxford University Press.

Strauss, A. C., \& Corbin, J. M. (1998). Basics of qualitative research. Thousand Oaks, CA: Sage. 
Tabak, I. (2004). Synergy: A complement to emerging patterns of distributed scaffolding. Journal of the Learning Sciences, 13(3), 305-335.

van Driel, J., Verloop, N., \& de Vos, W. (1998). Developing science teachers' pedagogical content knowledge. Journal of Research in Science Teaching, 35(6), 673-695

Veal, W. R., \& MaKinster, J. G. (1999). Pedagogical content knowledge taxonomies. Electronic Journal of Science Education, 3(4). Retrieved May 1, 2011, from http://wolfweb.unr.edu/homepage/crowther/ejse/vealmak.html.

Welch, W. W. (1979). Twenty years of science curriculum development: A look back. Review of Research in Education, 7, 282-308.

Wood, D., Bruner, J. S., \& Ross, G. (1976). The role of tutoring in problem solving. Journal of Child Psychology and Psychiatry, 17, 89-100.

Zembal-Saul, C., \& Dana, T. M. (2000). Exploring the nature, sources, and development of pedagogical content knowledge for supporting children's scientific inquiry (PCK-SI). A paper presented the annual meeting of the National Association for Research in Science Teaching, New Orleans, LA.

Zembal-Saul, C., Krajcik, J., \& Blumenfeld, P. (2002). Elementary student teachers' science content representations. Journal of Research in Science Teaching, 39(6), 443-463. 